\title{
Suzel Esquier, De la comédie humaine au théâtre: "Vautrin"
}

\section{Marco Stupazzoni}

\section{(2) OpenEdition}

\section{Journals}

\section{Edizione digitale}

URL: http://journals.openedition.org/studifrancesi/3791

DOI: 10.4000/studifrancesi.3791

ISSN: 2421-5856

\section{Editore}

Rosenberg \& Sellier

\section{Edizione cartacea}

Data di pubblicazione: 1 décembre 2012

Paginazione: 589

ISSN: 0039-2944

\section{Notizia bibliografica digitale}

Marco Stupazzoni, «Suzel Esquier, De la comédie humaine au théâtre: "Vautrin"», Studi Francesi [Online], 168 (LVI | III) | 2012, online dal 30 novembre 2015, consultato il 07 mars 2021. URL: http:// journals.openedition.org/studifrancesi/3791 ; DOI: https://doi.org/10.4000/studifrancesi.3791

Questo documento è stato generato automaticamente il 7 mars 2021.

\section{(c) (†) $\ominus$}

Studi Francesi è distribuita con Licenza Creative Commons Attribuzione - Non commerciale - Non opere derivate 4.0 Internazionale. 
Suzel Esquier, De la comédie humaine au théâtre: "Vautrin"

Marco Stupazzoni 


\section{NOTIZIA}

SUZEL ESQUIER, De la comédie humaine au théâtre: "Vautrin", in Aa. Vv., Odeporica e dintorni. Cento studi per Emanuele Kanceff, a cura di Pino MENZIO e Chiara KANCEFF, 4, Moncalieri, C.I.R.V.I., «Biblioteca del viaggio in Italia. Studi», 2011, pp. 1595-1610.

1 Protagonista assoluto della trilogia romanzesca che comprende: Le Père Goriot, Illusions perdues e Splendeurs et misères des courtisanes, vera e propria colonna vertebrale dell'organismo finzionale della Comédie humaine e riflesso speculare del pensiero di Balzac sull'uomo e sulla società, il personaggio di Vautrin fornisce allo scrittore l'occasione per un nuovo (e altrettanto deludente per la ricezione ottenuta) tentativo drammaturgico nell'anno 1840.

In questo studio, l'A. si propone di analizzare le interferenze tra la scrittura romanzesca e la produzione teatrale di Balzac, mostrandone contemporaneamente le alterazioni profonde, così «déroutantes pour le lecteur familier de l'univers romanesque» (p.1596). La figura di Vautrin rende fortemente palese la vocazione teatrale di Balzac: rispetto alla sua identità (proteiforme) ed al suo ruolo nella Comédie humaine, il Vautrin del dramma omonimo appare «trop morcelé», troppo calcato sui modelli dell'ex-forzato Vidocq e di Robert Macaire. Il dramma stesso si situa, per quanto concerne la «question du décor», agli antipodi del romanzo. Ma un altro aspetto evidenziato bene dall'A. merita di essere sottolineato: "pour créer le personnage de Vautrin», scrive S. Esquier, Balzac «a puisé encore et davantage à une autre source: celle du mélodrame, mais du mélodrame deuxième manière, du mélodrame adultéré» (p. 1606), attraverso cui può esplicitarsi il sarcasmo politico dello scrittore nei confronti di una società ormai moralmente in decomposizione. 